\title{
The effects of rain and fallen debris on macroinvertebrate colonization of artificial water tanks and their implications for bromeliad communities
}

\author{
Julián Monge-Nájera' ${ }^{1}$ \& Kyle Gename ${ }^{2}$ \\ 1. Biología Tropical, Universidad de Costa Rica, 11501-2060 San José, Costa Rica; julianmonge@gmail. com (Corresponding Author). \\ 2. Macalester College, 1600 Grand Ave. Saint Paul, MN 55105 USA; kgename@macalester. Edu
}

Received 16-VII-2013 • Corrected 24-X-2013 • Accepted 23-I-2014

\begin{abstract}
Bromeliads are important components of tropical forests and their leaves form tanks ("phytotelmata") with unique microecosystems. Until recently, there were no experiments of how macroinvertebrates reach these tanks. We placed 150 plastic cups ("artificial bromeliads") in a Costa Rican forest and found that when debris and rain are experimentally blocked, some groups are not found in the tanks (including the medically important (ulicidae) or differ in frequency between treatment and control.
\end{abstract}

KEY WORDS: tropical ecology, bromeliad experiments, Culicidae in phytotelmata, Costa Rica, microhabitat colonization.

\section{RESUMEN}

Las bromelias son componentes importantes de los bosques tropicales y sus hojas forman tanques con microecosistemas únicos. Hasta hace poco no había estudios experimentales de cómo llegan los macroinvertebrados a esos tanques. Colocamos 150 vasos plásticos ("bromelias artificiales") en un bosque de Costa Rica y hallamos que cuando se evita experimentalmente la caída en ellos de residuos y lluvia, algunos grupos no se encuentran (incluyendo Culicidae, un grupo de importancia médica) o difieren en frecuencia entre tratamiento y control.

PALABRAS CLAVE: ecología tropical, experimentos con bromelias, Culicidae en tanques artificiales, Costa Rica, colonización de microhábitats.
There are few studies on how ecological factors such as precipitation and debris influence organisms that colonize bromeliad tanks ("phytotelmata") and how they reach these microecosystems.

Debris and rainwater are important resources for bromeliad communities; water volume and detritus contents affect species richness (Picado, 1913; Armbruster, Hutchinson \& Cotgreave, 2002) and some arachnids prefer tanks with more water and less debris for oviposition (Osses, Martins, \& Machado, 2008).

Picado (1913) mentioned that some invertebrates could fly or walk to bromeliads but hypothesized that others reached the plants passively in rain and debris, among other mechanisms, and phoresis involving bromeliad ostracods and annelids has been reported from Brazil (Lopez, Filizola, Deiss, \& Rios, 2005). Recently, Gename and Monge-Nájera (2012) tested Picado's (1913) rain and debris hypotheses with field experiments in Costa Rica, and found that artificial tanks accumulated different numbers of invertebrates when rain or debris were prevented from reaching the tanks. However, that report did not mention the taxonomic composition of the invertebrates because such data were not available at the time. This communication is a follow-up of that article and presents the first data on how particular invertebrate groups differed in these colonization experiments.

The field site and the experiments were described in detail previously (Gename \& Monge-Nájera, 2012). Briefly, we placed 150 plastic cups that served as «artificial bromeliad tanks" in a forest with naturally occurring bromeliads in Turrialba, Costa Rica. The experiment could also be done by sterilizing natural bromeliads to start controlled colonization but we did not wish to damage existing communities (Srivastava, 2006). Some cups had covers that prevented debris from falling inside, some had covers that prevented the entrance of rain and some had no covers and acted as controls. The covers did not prevent the entrance of small animals (see below). 
Water level was maintained artificially throughout the experiment with distilled water. Distilled water was used to avoid the accidental introduction of eggs and microorganisms that could obscure the results.

After seven weeks, the invertebratesinsideall cupswere preserved in $70 \%$ ethanol and identified in the laboratory to the lowest possible taxon. There is no comprehensive or updated guide to the taxonomy of bromeliad invertebrates (Frank \& Lounibos, 2009), but we identified the specimens to the lowest taxonomic group possible for us. When debris and rainwater were experimentally blocked from reaching the artificial bromeliads, some insect groups were not present in the tanks and others differed in abundance from the control ( $p<0.0001$, Fig. 1); the differences with the control were smaller or not significant for the less common groups (Annelida $p=0.0098$ for debris versus rain but no difference with the control; Arachnida $p=0.0937$; all tests: Kruskal Wallis ANOVA, $\mathrm{n}=50$ cups per treatment for a total of 150 cups).

Earwigs (Forficulina) and the medically important mosquitoes (Culicidae) were absent in the tanks where debris were blocked. These are groups that can fly or walk to the tanks and their entrance was not blocked (there was open space over the cup rims, see figure 1 in Gename \& Monge-Nájera, 2012), so the absence of debris biomass might have prevented them from finding a food source (culicid larvae are filter feeders and earwigs are omnivorous). The frequency of two groups of predators -larval coleopterans and spiders (Mygalomorphae)was lower in the treatments (Fig. 1), perhaps debris are needed to bring enough food into the system for a significant prey populations to exist.

Cockroaches (Blattaria), which are omnivores, were relatively frequent in the tanks without debris, while a variety of insect groups that were absent in the controls appeared in small numbers in the tanks without debris or rain (Fig. 1).

Tanks isolated from rainfall had few culicid mosquitoes and earwigs (Fig. 1). These tanks had distilled water and so it lacked any micronutrients, organic matter and microorganisms that would be expected to occur in rainwater. On the other hand, in comparison with the controls, two groups were more frequent in the tanks without rainfall: coleopterans and cockroaches. Both are terrestrial and feed on animal tissues (cockroaches are omnivores and some coleopterans are herbivores in part of their cycle).

Recent experimental work found that the presence of spiders in bromeliads can cause an unexpected increase in the number of oligochaetes and ostracods. The reason is that spiders prey on detritivore larvae, diminishing the competition for those other groups (Ngai \& Srivastava, 2006; Srivastava \& Bell, 2009; Romero \& Srivastava, 2010). A similar mechanism may have operated in our case when debris were prevented from falling into the tanks: the absence of culicids, a very important group in these microhabitats (Frank \& Lounibos, 2009) might have left more food for the oligochaete worms, while the reduction in nutrients (normally brought into the system by the debris) can explain why there were less coleopteran predators, a probable result of reduced prey populations.

Many microscopic species inhabit bromeliad tanks and are even less known than the macroinvertebrates that we analyze in this article (Picado, 1913; Frank \& Lounibos, 2009). These species cannot walk or fly to reach the bromeliads so they are probably carried by the wind and the rain and its runoff (Picado, 1913) or even on the bodies of invertebrates and vertebrates, either as eggs or in more advanced stages of their life cycle (Lopez, Filizola, Deiss, \& Rios, 2005). But we know very little about this phenomenon (Gename \& Monge-Nájera, 2012).

We found that cups isolated from the rain lacked oligochaetes; this is in accordance with the rain hypothesis but requires careful experimental work because these systems are extremely complex (Jabiol, Corbara, Dejean, \& Céréghino, 2009) and some oligochaetes are known to be carried by frogs (Lopez, Filizola, Deiss, \& Rios, 2005), which might have found the space above cup rims too small.

The groups that appeared to benefit when rain water was blocked (coleopterans, and possibly also cockroaches and spiders) are all terrestrial and feed on animal matter (Frank \& Lounibos, 2009). They may somehow have advantages in a microhabitat that is not affected by the frequent and heavy rains of the tropical rainforest, but this, as well as the groups that appear only in tanks isolated from rain or debris, can only be clarified by new research that ideally will consider one problem at a time and will have treatments and proper controls. Other factors to consider in the future are the color of the cups, their shape and their lack of structural complexity created by leaf bases (see the experiments of Srivastava, 2006). Furthermore, we found lepidopterans and orthopterans, groups that are not common bromeliad dwellers (Picado, 1913). Nevertheless, it is clear from our results that debris and rain have an effect on which macroinvertebrate species are found in experimental water tanks.

We consider the explanations suggested here as no more than a source of hypotheses for future researchers. They could not only repeat our studies to see if they obtain similar results, but also could apply similar methods to other inhabitants of phytotelmata such as protozoans, 

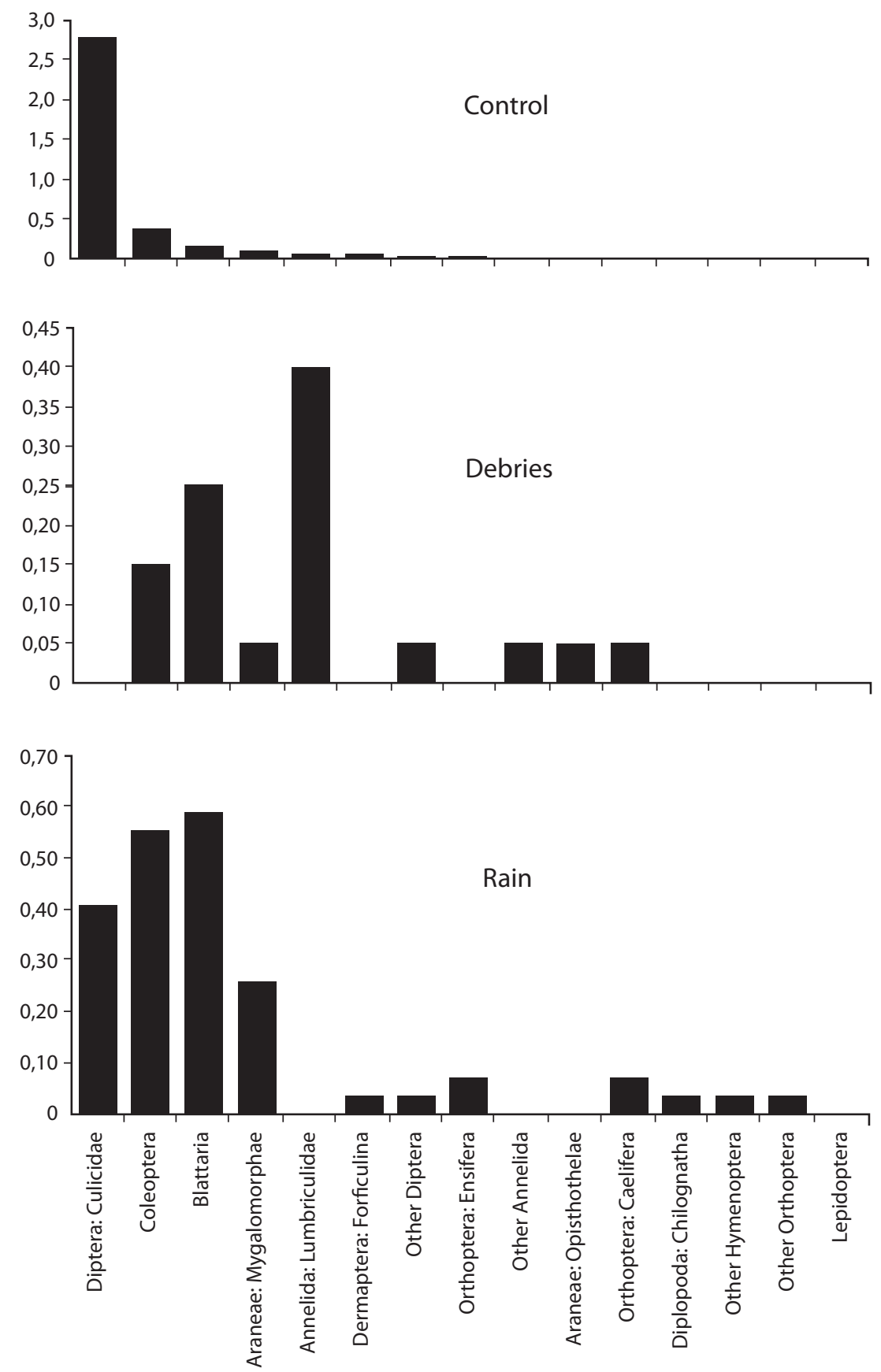

Fig. 1. Mean number of invertebrates (specimens/bromeliad) per taxonomic group in three experimental treatments: control, bromeliads where debris were prevented from falling inside the water tank, and bromeliads where distilled water was kept artificially but rainwater was prevented from reaching the tank. The scales are not the same to save space. 
bacteria and fungi. There are many unanswered questions about the organisms living in bromeliads and other phytotelmata and how they colonize these plants. Interest, observation, experimentation and patience are more important than funds, as hopefully our minimum budget study shows.

\section{ACKNOWLEDGMENTS}

We thank Karla Vega and Sergio Aguilar for assistance with the figure, the Associated Colleges of the Midwest for support to KG and six anonymous reviewers for their support and comments.

\section{REFERENCES}

Armbruster, P., Hutchinson, R. A., \& Cotgreave, P. (2002). Factors influencing community structure in a South American tank bromeliad fauna. Oikos, 96(2), 225-234.

Frank, J. H., \& Lounibos, L. P. (2009). Insects and allies associated with bromeliads: a review. Terrestrial Arthropod Review, 1(2), 125-153.

Gename, K., \& Monge-Nájera, J. (2012). How organisms reach and colonize bromeliads: a field experimental test of two of Picado's hypotheses, and the effect of tree age and cardinal distribution on bromeliads in Cartago, Costa Rica. Cuadernos de Investigación UNED, 4(2), 181-186.
Jabiol, J., Corbara, B., Dejean, A., \& Céréghino, R. (2009). Structure of aquatic insect communities in tank-bromeliads in a East-Amazonian rainforest in French Guiana. Forest Ecology and Management, 257(1), 351-360.

Lopez, L. C. S., Filizola, B., Deiss, I., \& Rios, R. I. (2005). Phoretic behaviour of bromeliad annelids (Dero) and ostracods (Elpidium) using frogs and lizards as dispersal vectors. Hydrobiologia, 549(1), 15-22.

Ngai, J.T., \& Srivastava, D. S. (2006). Predators accelerate nutrient cycling in a bromeliad ecosystem. Science, 314(5801), 963.

Picado, T. C. (1911). Les Broméliacées épiphytes comme milieu biologique. Comptes Rendus de l'Académie des Sciences, 153,960 .

Osses, F., Martins, E. G., \& Machado, G. (2008). Oviposition site selection by the bromeliad-dweller harvestman Bourguyia hamata (Arachnida: Opiliones). Journal of Ethology, 26(2), 233-241.

Romero, G. Q., \& Srivastava, D. S. (2010). Food-web composition affects cross-ecosystem interactions and subsidies. Journal of Animal Ecology, 79, 1122-1131.

Serramo, L. C., Filizola, B., Deiss, I., \& Iglesias, R. (2005). Phoretic behaviour of bromeliad annelids (Dero) and ostracods (Elpidium) using frogs and lizards as dispersal vectors. Hydrobiologia, 549 (1), 15-22.

Srivastava, D. S. \& Bell, Thomas. (2009). Reducing horizontal and vertical diversity in a foodweb triggers extinctions and impacts functions. Ecology Letters, 12, 1016-1028. 